\title{
The School Bus Symposium: A Poetic Journey of Co-created Conference Space
}

\author{
Mitchell McLarnon ${ }^{1}$ \\ McGill University \\ mitchell.mclarnon@mail.mcgill.ca \\ Pamela Richardson \\ Royal Roads University \\ pamela.1richardson@royalroads.ca \\ Veena Balsawar \\ University of Ottawa \\ vbalsawer@gmail.com \\ Kathy Browning \\ Laurentian University \\ kbrowning@laurentian.ca \\ Lynn Fels \\ Simon Fraser University \\ lynn_fels@sfu.ca \\ Anja Human \\ North-West University \\ 20669003@nwu.ac.za \\ Carl Leggo \\ University of British Columbia \\ carl.leggo@ubc.ca \\ Kathy Mantas \\ Nissiping University \\ kathym@nipissingu.ca \\ Silvia Morelli \\ Universidad Nacional de Rosario \\ silviatmorelli@hotmail.com \\ Sean Wiebe \\ University of Prince Edward Island \\ swiebe@upei.ca \\ Marni Binder \\ Ryerson University \\ mbinder@ryerson.ca \\ Diane Conrad \\ University of Alberta \\ diane.conrad@ualberta.ca \\ Peter Gouzouasis \\ Universtiy of British Columbia \\ peter.gouzouasis@ubc.ca \\ Eun-Ji Kim \\ McGill University \\ eun-ji.kim@mail.mcgill.ca \\ Amélie Lemieux \\ McGill University \\ amelie.lemieux@mail.mcgill.ca \\ Karen Meyer \\ University of British Columbia \\ karen.meyer@ubc.ca \\ Robert Nellis \\ Red Deer College \\ robert.nellis@rdc.ab.ca \\ Julie Vaudrin-Charette \\ University of Ottawa \\ jvaudrincharette@gmail.com
}

\begin{abstract}
With the intention of disrupting and re-imagining traditional conference spaces, this article is a poetic compilation developed from a curriculum studies conference symposium that took place on a school bus. During the School Bus Symposium, in situ poetry writing and reading, song and storytelling occurred in response to open ended prompts and facilitation of creative activities. After the symposium, a call was
\end{abstract}

${ }^{1}$ Biographical statement: The School Bus Symposium was initially imagined by Sean Wiebe and Pamela 
issued to invite participants to submit any poetry or stories produced during, or inspired by the session. Consisting of 18 submissions including poetry, story, photography and creative essays, infused by curriculum theory and poetic inquiry, this collection offers an inclusive, reflective, reflexive, participatory, and experiential rendering where participants are living and journeying poetically. Emphasizing creative engagement with personal memories and the surrounding environment from the moving school bus, the authors collectively aimed to promote art education through imaginative approaches to curriculum studies, poetic inquiry and academic conferences.

Keywords: curriculum studies; poetic inquiry; art education; participatory approaches; conference symposiums. 


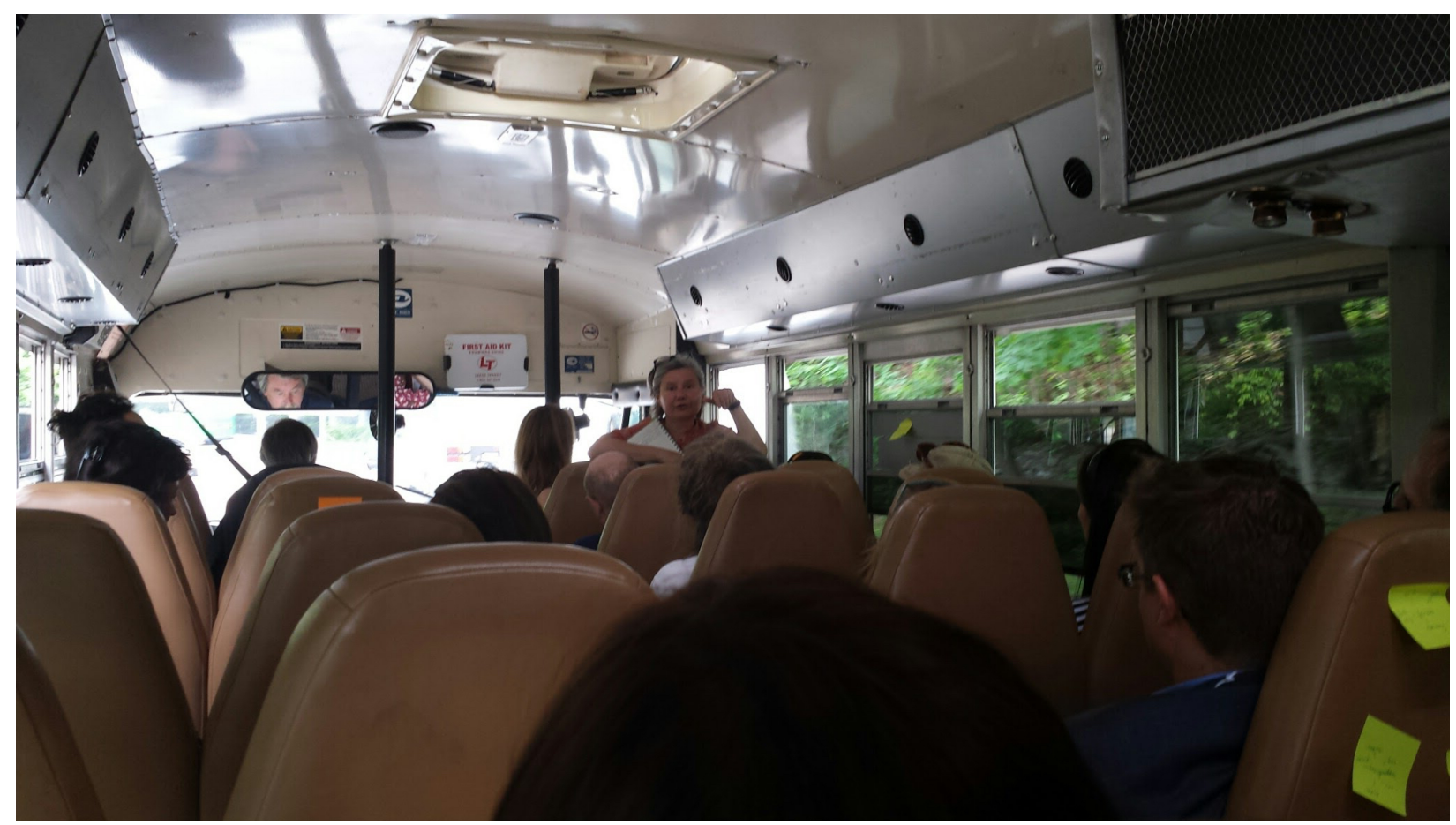

Figure 1: Found poetry with Diane Conrad. Photograph by Veena Balsawer

In May 2015, at the International Association for the Advancement of Curriculum Studies (IAACS) conference in Ottawa, Canada, a group of 30 scholars shared artistic, aesthetic and poetic expressions on a chartered school bus. With the twofold hope of engaging participants in an experiential journey and creating a new and imaginative space for a conference presentation that disrupts normative transmissive approaches, we rented a school as part of our ongoing arts education advocacy to co-create more participatory sessions at conferences. Attendees were encouraged to connect with the sensate realm and reflect on memories of taking the bus to school, exploring its unique "place" in the educative journey.

Together we set out to visit diverse neighbourhoods in Ottawa, stopping occasionally to mimic the process of collecting children for the school day. In situ poetry readings, poetry creation activities, and storytelling were all part of the 90-minute session to stimulate and simulate childhood recollections. The sharing of poems and stories were structured to promote dialogue amongst conference participants. Often playful, and just as often serious, some presentations were quietly read to a silent audience, while other poems/presentations evoked panic, laughter and singing. This approach provided an opportunity for participants to write their own poetry in a responsive and reflective way. Designed for poet and non-poet participants to live poetically (Leggo, 2007), after this shared experience, we invited participants to submit the poetry they wrote during the session towards creating this collaborative article.

Our call for contributions emphasized the sensory and experiential notion of the journey while making explicit connections to how creativity can be employed in 
contemporary curriculum. Greene (1988) describes this as the "conscious adjustment of the new and the old" (p. 124). This compilation, inspired by Eisner (2002), considers "the quality of the journey as more educationally significant than the speed at which the destination is reached" (para. 42). Greene (1995) further says that while we cannot return to the "landscape of those prereflective days," we can be present with our current landscape by reflecting on it, and by doing so "we become far more present to our enmeshed and open-ended selves" (p. 73). Using the lived experience of the School Bus Symposium to invite inquiry and creative engagement with personal memories, we asked for poetic explorations of "curriculum-as-lived experience" (Aoki, 1991, p. 161).

As the many submissions created different kinds of tensions and possibilities within the text, we made minor edits to avoid repetition, creating new layers and entanglements. In shaping the text, we were guided by the intention to equalize different perspectives of the contributors, highlighting multiple layers, and communicating the evocative placements that were found through our reflections and experiences. In this way, we hope to "synthesize experience in a direct and affective way" (Prendergast, 2009, p. xxxii). It was also our aim to emphasize the out-of-class experience and its influence on how curriculum is lived (Aoki, 1991; 1993). As we disrupt conference spaces, we consider other out-of-class spaces just as vital as inclassroom spaces.

Each school day, students and teachers interact in hallways, on the school grounds, and in the cafeteria. Situated more personally in relation to the social aims of education, the interactions that take place outside of the traditional classroom often unfold in more poetic ways, giving space for more authentic self exploration. Campano (2007) refers to learning that takes place in the margins of the school as the "second classroom" (p. 39). According to Campano, the second classroom is an alternative, pedagogical space that develops organically by following interests, desires, forms of cultural expression and stories of students.

Campano's (2007) notion of the second classroom relates to what Eisner (1985) describes as the null curriculum. Eisner (1985) shows that there are three kinds of curriculum that all schools teach: the explicit, the implicit and the null. The explicit curriculum is the kind that is published in policy documents and outlines educational outcomes. The implicit curriculum refers to the type of learning that students will grasp from the way school, schooldays, and classrooms are structured. Eisner (1985) describes the null curriculum as subjects, locations, and approaches (pedagogy) that are available but not employed. The unemployed areas are often forgotten, as they are not noticeable and recognized by students, teachers, administrators, policymakers and the general public. While we were unable to address all aspects of the "second classroom" (Campano, 2007, p. 39) and the "null curriculum" (Eisner, 1985, p. 97), in this article, we seek to pay tribute to the forgotten and unemployed areas of school and curriculum through a poetic journey on school bus.

In the following pages, you will read a collection of poems that simulate our memories and reflections. At times, this article may feel discursive as we collectively 
ride the bus through time and from place to place. Some authors have opted for speculative and theoretical text complemented by poetry. Others have chosen an aesthetic approach whereby their entire contribution is written in poetic prose. You will also encounter comical, and mischievous poems that represent the playful nature of this conference symposium and article. Specifically, the poems reflect how a school, and a school bus can be captive space within which there is unpredictability, uncertainty and diverse perspectives. We allude to relations of power and social structures that take place in school and on a school bus. Entering the bus, participants did not know with whom they would sit and where (or if) the bus would be stopping.

Through poetry we move fluidly between spaces and subjects. It is important to note that for the purpose of this publication, we did not primarily attend to the question of "is this a good poem?" As this was not our objective, rather, we focused rather on disrupting current conference spaces/practices, and through poetic creation and response, offer new lines of relationship with one another, our memories, and with the iconic place of the school bus in our educational journeys. We hope that our poems evoke and generate your own reflections about teaching, learning, and the potential of curriculum.

\title{
The Poems
}

\section{Who is Driving this Bus Anyways?}

\author{
Julie Vaudrin-Charette, PhD Candidate, University of Ottawa
}

Entering the space of the School Bus Symposium triggered living memories of power, play and languages in relationship to education. Re-exploring the initial triggers provided a fertile field for exploring how these memories might be infused with transformation. For this publication, I looked back at two notes and a two minute poem from the Symposium as entry points.

First note. Dé[tours]ne ment or a truthful re-shifting power.

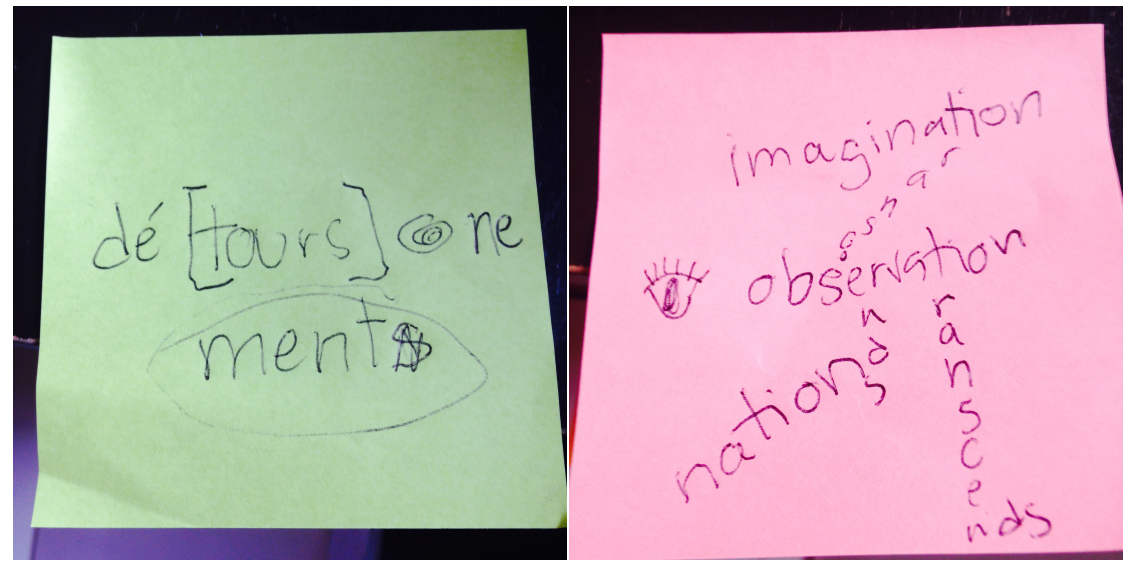

Figure 2 \& 3: Photograph and found poetry notes by Julie Vaudrin-Charette 
Sitting on a bus makes me exuberant. I look at other grown-ups entering the space, and how the space transforms us. Speaking louder, singing, laughing. Going on a journey. Re-entering the school bus as adult, transcends the geographic journey it may involve. It brings us into a journey of exploring how power relations hide in our daily interactions (Bourdieu \& Thompson, 1991). Although the driver holds a position of explicit (assumed) power, the context (when the bus starts moving) creates an occasion for students to deconstruct some of the implicit (untold) power relations at stake between them. In order words, once the bus starts moving, chaos prevails. The driver keeps the passengers safe. To do this, he needs to focus on the road, hence becoming more exposed to whatever might emerge from the children. Now, transposing the driver into an educational metaphor, one might examine how some contexts provide spaces for an educator to be in control, yet, vulnerable, and how we negotiate those tensions as educators.

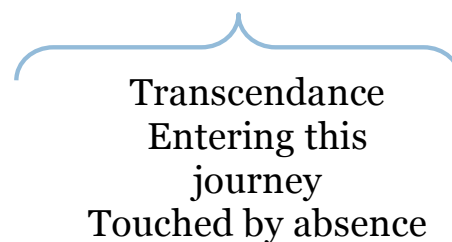

Descendance Entering ancestry Through presence

Transformance Within body Absence breathes Presence.

Figure 4

\section{Second note. Imagination Transcends Observation Transcends Nation.}

Personally, I observe this tension between control and vulnerability also echoes our responsibility towards social justice. As an educator, how can I engage in repairing past trauma, within myself, and with others? Using language(s) as praxis opens new ways of listening to a charged colonial past (Simon, 2012; Tuck \& GaztambideFernández, 2012; Stanley, 1999), cultures, and citizenship (Byram, 2010). In fact, repairing some of the impacts of the annihilation of educational rights to language(s) (Egéa-Kuehne, 2012) cannot be achieved without re-claiming indigenous languages and place-based learning (Simpson, 2014; Battiste, Kovachs, \& Balzer, 2010; Chambers, 1999; Blood, Chambers, Donald, Hasebe-Ludt \& Big Head, 2012; Farley, 2009). As the bus starts moving,

I look out the window

and dream that imagination transcends nations.

\section{Instant poem. Treating Play Seriously.}

At this point in the journey, I am almost tired.

Vygotsky's (1967) theory on play in language development comes to the rescue, whispering a different relationship to rules, emphasizing how every imaginary situation contains rules of behaviour and vice-versa: every game with rules contains an imaginary context (David, Goouch \& Powell, 2015). As such, in play, a new relationship is created between the semantic and visible fields - that is, between situations in 
thought and real situations. In play, language becomes tool-and-result (Holzman, 2008), and creates developmental learning spaces. This is also explored in the lineage between storytelling and indigenous epistemologies (Corntassel, 2009; Falconi, 2013).

So I enter the task of writing a poem playfully, in 120 seconds, de-dramatizing language learning; mistakes, mispronunciations, explanations about the meanings of certain words are part of my learning journey.

And I write about an innerjourney.

Hence, the operational framework of the school bus provided a space to reverse power relations, dream reconciliation, and accept to be transformed by context. Not bad for an hour and a half workshop.

\section{Shine a Moon}

Peter Gouzousis, University of British Columbia

In reminiscence of post soccer games in high school, riding home on a yellow school bus after a win (whoever scored a goal had to "shine a moon" out a bus window to shock drivers in cars during rush hour traffic). We were undefeated in junior year, and only lost one game senior year - we showed a lot of skin those years.

\section{Post soccer game on a yellow school bus}

Pulling pranks

Pulling hair

Pulling down your underwear

Pee pee pee

Shame on me

Is this really poetry?

\section{Found poem on a suburban Ottawa bus ride}

Bluebird, be calm, quiet.

Don't panic-first aid is made to capacity.

Quickly pushing or shoving,

Provides maximum restructuring,

Starting danger instructions.

Elegant waxing wind,

All in complex recreation.

Smile, you're on camera,

Bring it! 


\title{
Home
}

(a found poem on a bus ride home)

Diane Conrad, University of Alberta

\author{
A special place \\ of comfort, safety \\ easy to come to \\ open doors \\ to just get in \\ and lounge in the company \\ of persons I value \\ those I can count on ... \\ but its a stoney paradise \\ caution, \\ a wild ride \\ just as easy to go ... \\ escape.
}

\section{Re-riding the School Bus from Donnacona to Quebec City}

Lynn Fels, Simon Fraser University

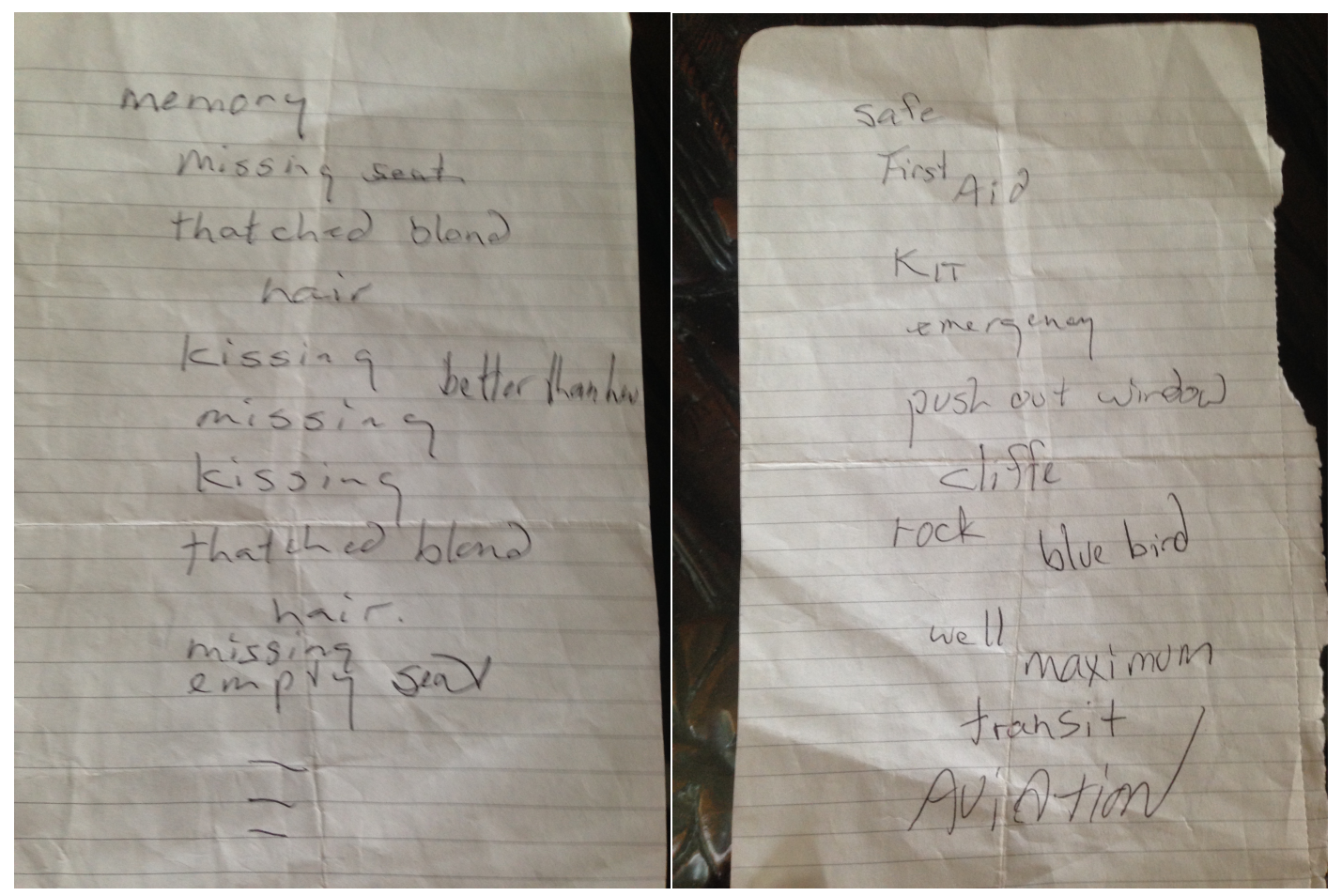

Figures 5 \& 6: Found poetry scribbles by Lynn Fels 
Two poems scrawled in pencil on lined paper on a school bus. Funny, reading them now, I recognize untold narratives embodied within the text...

First kiss by a first boyfriend, his former girlfriend haunting the moment, our newspaper boy, thatched blond hair coated with snow, standing at our kitchen door, language stands between us, Jacques, dead at fifteen, on display in an open coffin, a brother's shared shock, intertwined with images of reluctantly riding adolescence on a yellow Blue Bird school bus.... Amidst the chatter of conference attendees boarding a bus commissioned for our presentation, I step with caution. Earlier, I woke in the morning light with the forgotten but familiar nauseous feeling of lying in bed waiting for my mother's call, I don't know if I can climb into that bus. A white school bus, not the yellow bus expected, waits for us curbside. A ghost bus! How do I climb those stairs through time, past the bus driver, a man of no welcome, trapped in his seat where his belly visibly swells year after year in glowering resentment, his eyes a cold stare in the rear view mirror. Where will I sit in the hierarchy of seniority, privilege, and popularity? What rules will guide us here? Relief as a friend tugs me into place. The back of the bus is forbidden territory. Time in transit, looking out a bus window across fields to a long stretch of river, until the bus turns off the highway, groans its way up the hospital hill, where once, wheels slip on black ice, and a popular girl (who shames and excites us kissing her boyfriend in the backseat next to the emergency door) yells, "The bus is going backwards! Quick! Everyone escape through emergency door!" We are trapped forever in these moments, moments that amuse, that trouble, that tug on our sleeve. Who is that girl, eyes averted, stomach churning, as her brother runs alongside the bus arrested in a timeless chase... here now, in this moment, surrounded by conference participants, I leap to my feet, pound on the window, "Stop! Stop the bus! My brother is coming!" I stride the length of the bus, invade. Now I am the one sitting at the back of the bus, listening to others tell stories of riding school buses, my stories, this conference presentation, this being on a bus together a catalyst and invitation to share memories. "My mom chased after the bus with me in the back seat, honking the horn all the way," "I hated climbing up the bus stairs with everyone looking." I am weightless, a nameless burden released. I OWN the bus! I AM one of the popular kids.... and damn it that bus driver will listen to me, put on the brakes and pull curbside. He will open the door and my brother will run up the stairs, breathless, and slip into the seat beside me, as I continue to slam on the window, yelling, "stop!"

\section{Riding the School Bus with Dr. Zhivago}

\section{Carl Leggo, University of British Columbia}

Grade ten. Riding the school bus. I always saw the same girl walking along Main Street on her way to another school. Seen through the bus window, I fell in love with her. Like Dr. Zhivago sees long lost Lara from a bus window and dies with a broken heart. I don't recall much about life on the bus-we were always packed into the bus by 
Buck who only ever barked one line: Move back! Move back! He repeated his order like a manic mantra. Buck never smiled. Move back! Move back! There was little moving in the bus. We were trapped, squeezed, squashed into a block of adolescence. Movement was outside the bus. Like a movie, I saw the circle of seasons, the slow parade of weeks, the somnambulant crawl of days. But mostly I saw the girl walking along Main Street. She was a distant star I could see but never know. I fell in love with the girl, and watched her every day. I never once considered shouting at Buck, Stop! I never once considered jumping off the bus, perhaps out the emergency door or through a window. Instead I just watched the back of the girl's head, then her face, seen briefly over my shoulder through a crack in Monty Mosher's blue nylon parka like a dark mountain that filled most of the window. I didn't wave or smile. As the girl walked along Main Street, often with another girl or two or three I can't remember at all, her blonde hair held sunlight and snowlight, and she always smiled like she knew I was watching and might write poetry about her when others had long forgotten.

\title{
Along a Yellow School Bus in Ottawa
}

\author{
Silvia Morelli, Universidad Nacional de Rosario (Argentina)
}

Beauty, everything is beauty. The sun shines in the yellow school bus. And it is filled with memories from childhood, from my own life, from my own story, warm and quiet. While we are traveling, a deep emotion surrounds my soul. What happens in Ottawa, so far from Rosario? The memories travel through time and space and I am still on my own. I feel like I am six years old in a yellow school bus in Ottawa, so far from my home, but not from my memories.
All is beauty, hope, future, love. All is beautiful, like it was when I was a girl. The school bus moves along the neighbourhoods and I move along myself, along my own history, stitching school memories seals in my soul. School is not uncommon to me, but it surprises me. I am a foreigner in Ottawa. I am so far home. A stranger is sharing her feelings to the Yellow School Bus. I remember my sons. I can't avoid bring to present their own stories of the yellow school bus and memories from the adventure in their childhood. Both are brave boys waiting for me in Rosario. And I wonder how many feelings from childhood they have and still don't know, how many memories they have that I don't know.

In the bustle, a wide-eyed girl, I keep the silence of introspection. The yellow school bus that takes me along Ottawa's neighbourhoods takes me along my school memories, a long time ago, so far away. Love is a beautiful colour. All is sunshine, wood, green, pace, emotion. They are traces of my childhood: a bright yellow school bus in a sunny spring afternoon in Ottawa. 


\section{Rock ‘Em Sock ‘Em Poetry}

Sean Wiebe, University of Prince Edward Island

As Pinar (2010) notes, in a close reading of Greene's lectures, "the point is to experience arts from the inside" (p. 1). The intensity of perception possible through artistic knowing can be "self shattering" (p. 2), he says, and comparing this self shattering to the regressive phase of currere, he says it is necessary to "extricate us from submersion in the banal" (p. 2).

Invited into a Felsian (2010) stop moment, I find myself sharing with Robert Nellis how my bus-riding days were linked to hockey road trips as our Prince George team regularly travelled to Quesnel, Williams Lake, Dawson Creek, Fort Saint John, and Grand Prairie as part of as part of a Northern B.C. and Alberta League. Recounting these days (thank you for listening, Robert), I am remembering and questioning the value of a hockey dominated childhood and adolescence.

\section{What Doesn't Kill Us}

To toughen us the coaches stopped the bus directing us to walk across a bridge deck that had no walkway, no shoulder, no railing why did the coaches stop here, at a place they knew would scare the living shit out of us, of course my size five foot slipped through the wide gaps in the steel my shoe falling 400 metres to an eager spring river for 30 minutes they waited on the bus while I crossed crying, crawling on hands and knees, ashamed of my fear, my weakness, and that I kept them waiting.

\section{Metaphysics of Embodied Schooling}

Amélie Lemieux, McGill University

School bus, couple wheels, where it all began

Untied shoelaces, rehearsed a thousand times

They said effort matters more than grades

That practice makes perfect

My report card does not reflect that side effect

My mirror says: finished homework

Presented with a question mark

Will this one deserve a sticker, get an A? 
It's not child's play, it's written in my dossier.

Reckoning the seeds of a journey

Teaching by example, she gratefully accepted that apple

One bite at a time, fully immersed in time travel

That laid the grounds for her life inquiry.

Where it began I saw the path of my childhood, I saw

The more miles I did, practice kicked in

Within my limits, asymptotes brush past the grounds

Within my miles, safe sometimes sound

Without my fears, landscapes in mind.

My vision and yours through a kaleidoscope

Disguised through trapezes and parallelograms

Collaboration for that final exam

Ifs sound like whens, embodying last drops of hope

Now the route is paved in our sun's shadow,

Half rusted license plate, obligations out of the window

Always on time, never a day late.

Escaping the ice box that dictates our success

For the warmth of the sun crafts our vision

We, an inverted Me,

Collect the crumbs of historical horizons

To form what we call a future dimension

There, without a sense of time, we embrace

Here, without limits of space,

How can we keep the pace?

Forget about the grades

Writing, erasing, trimming, rewriting

Nothing is certain nor finished

How could it be, for ideas are constantly in movement?

In a fixed moment

Perception and subjectivism win the terrain.

Looking back at that school bus, sitting straight

My destiny fueled with each mile on these used wheels

Replaced with new ones year after year

Dark and light traces on our asphalt

Not altering its shape though changing its colour

When our ideas come together as gestalt

What serves as terrain goes back to the start. 


\title{
The Musings on the Bus Go Round and Round
}

\author{
Marni Binder, Ryerson University
}

School buses should be yellow

With green seats and stuck windows

And be loud...

I entered a white school bus

With brown seats and stuck windows

And it got loud...

99 bottles of beer on the wall

99 bottles of beer

Take one down pass it around

98 bottles of beer on the wall.

I did not take a school bus to go to school when I was younger. I walked. However, I spent much time on school buses as a child going on field trips, and as teacher of young children. Growing up in Ottawa, my rekindled memories were filled with images of places we passed on the bus journey that have become part of my living landscape: The Ottawa River with Hull across the bridge; Sussex Drive as it wound through the political wealth of the Prime Minster's residence and Rockcliffe Park. Familiar street names pulled at my recognition. I found myself smiling as we journeyed through the different neighbourhoods and past times.

And while looking back, the changing landscape called my attention to the present.

\author{
98 bottles of beer on the wall \\ 98 bottles of beer \\ Take one down pass it around \\ 97 bottles of beer of the wall. \\ school bus memory \\ the odds \\ kissing boyfriend \\ young love on back seat \\ happy travel where \\ life continues \\ the spontaneity of \\ you \\ we.
}

Pamela, I did not throw wads of paper at you while you were reading your poem. Honest! A gentle breath, a waft of wind picked up the stickie note and it drifted to your 
face. You didn't have to pick on me! It was a fluttering stickie. It was synchronistic timing. How was I to know? Why did you have to be the one person on the bus to pick on me? Ah... playing.

97 bottles of beer on the wall

97 bottles of beer

Take one down pass it around

96 bottles of beer on the wall.

Found poetry of words, images, sounds and conversations that resonated along the way.

An expanse of water

Two solitudes of

Waterways

Steadfast

Bluebird

Exits

American Graffiti Garage

First aid

Emergency exit

Fire route

Arrêt

Stop.

96 bottles of beer on the wall

96 bottles of beer

Take one down pass it around

I wonder how long it would take for us to get to

1 bottle of beer on the wall?

Another lived bus trip?

\section{The Social Hierarchy of School Buses}

Mitchell McLarnon, McGill University

'Twas the first day of school and all through the bus the students were seated by social status.

With the youngins up front is where I nervously sat hoping that one day l'd sit in the back.

The big kids were scary, and hairy, and loud and I knew for certain I wanted part of that crowd. 
They knew about music and bought their own lunch.

I brought my own, and in it, fruit punch.

Years later, grade six, and I had the back.

Shutting and slamming, the windows went "crack".

I loved the bumps and knew how to jump.

This bothered the bus driver; he was a big grump.

His name was "Monsieur" and being quite blunt

"Stop misbehaving or back to the front!"

\section{Hidden Curricula}

Anja Human, North-West University, Potchefstroom Campus

I love reading poetry as well as writing my own. My poems come spontaneously; usually the words burst out of my soul. I guess this was one of the main reasons I had been looking forward to the School Bus Symposium ever since I received the first e-mail about it. On the bus we used new strategies to create poems that were different from those I was used to.

This will be the first time that I am sharing my poems publicly. Below are the two poems that I crafted on the bus.

\section{School bus humiliation}

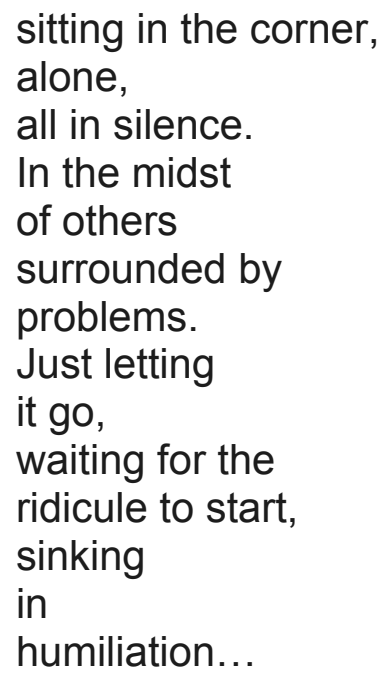

\section{Daydreaming on the bus}

Staring into the distance

Drifting off on a cloud... 
To a faraway land,

filled with colourful flowers, green trees, clear blue skies, silence, tranquility...

Laughter breaks out.

Snatched back into reality!

Staring into my own reflection

The bus came to a stop.

Reflecting on events of the School Bus Symposium and re-thinking curriculum, several questions come to mind. What do children learn while they are in the school bus? What are the social and hidden curricula conveyed with each school bus ride?

My poem about the school bus humiliation was born out of a phrase given to us during the symposium. It was about a child that wet her pants on a school bus. When a child wets her pants, could this be an indication of something deeper going on in their heart? And do people often choose just to overlook this? When someone wets his or her pants, it could be a cry for help.

Sometimes daydreaming is an escape from reality and also an indication of something deeper, something that might be going wrong in that child's life. The marginalized often feel a sense of estrangement from the dominant culture (Robinson \& Sharma, 2015) and could school bus rides more easily contribute to these feelings? Reading poems is about perceiving hidden messages - and so is growing up and riding a school bus. Often it is these hidden messages that construct our beliefs about who we are, about our identity. This is why I believe that, while discussing school bus rides, both the social and hidden curricula should be part of the conversation.

\section{Bus Stop}

Kathy Mantas, Nissiping University

Imagine if we designed all aspects of [school bus] travel [and teaching and learning] with the soul in mind - schedules, seating, pace, [stops], routes, machines, and terminals (Moore, 1996, p. 142).

It//inter-rupture], indeed, suggests more than interrupting that brings a time-out; it suggests complete undoing. Yes, complete undoing is exactly what ... [travel on the yellow school bus] does (Dubose Brunner, 1994, p. 39).

\section{Bus stop: a wait, a break, a rest, an interval}

At the moment, sitting on a white school bus 
not the usual school bus yellow

that I remember

beside my young daughter

almost seven

who is doodling,

on bright pink sticky notes,

concentric hearts, squiggly lines

resembling hearts beating,

chatting and sketching words

Sat, bat

Tires pull

"Can we do math?"

No cat

"I hardly see anything!"

Bus moving too fast

Stop

In the more recent past

following anxiously

in my car

the yellow school bus

that picked up my daughter

who was four

to bus her to school

from home at 8:00 a.m.

for the first and last time

but buses were not always

spaces filled with tears and fears

\section{Bus stop: an interim, a pause, an interlude, a recess}

In the past,

guiding animated students

toward the yellow school bus

for a journey

standing in the school bus

counting heads

checking on schoolchildren

passing out snacks

sharing stories about travel

upcoming adventures

And simultaneously

busing

through unknown cities 
provinces and countries

seeing through

strangers eyes

as if for the first time

hospitality given to

and received by

the host to the stranger

and the stranger to the host

Bus stop: an interruption, an invitation, and inter-rupture

In the distant past

directed by engaged teachers

onto the yellow school bus

sitting beside eager classmates

staring out the windows

sometimes moving too fast

opening, pulling, pushing

windows and doors

other times exiting

to gardens and

parkways of light

Two Found Poems

Eun-Ji Amy Kim, McGill University

\section{Poem \#1: Found-words poem (written on the bus)}

Ça c'est la yellow school bus.

Sigh.

So much going on.

Word

Email

Culture

Partegez.

Lost.

I am outside.

Pretty bad.

Finding emergency exit.

Excellent! 
Coconut Chemin North River,

Finally my old home

McArther Ave.

Hey, how did you get back here?

417 East? 417 Ouest?

Missing,

my wild geese family.

Where is my memory?

Crawling,

on my memory ave.

Dancing,

on my memory highway.

On my own.

Debut,

Begins.

\section{Poem \#2: Reflection (written on the bus)}

In the midst of chaos,

experience the formation of love, laughter and learning.

In the midst of disorder and order, complex yet beautiful knowledge

come to us

Out of nowhere.

The yellow school bus,

A bridge, between chaos and

beautiful stuffs.

Two words can sum up my experience on the School Bus Symposium:

Curriculum-as-beautifully-lived and orderly disorder (Doll, 2012). I remember, out of nowhere, songs were sung, accompanied by cheerful clapping and laughter without anybody giving the instruction to do so. Simple melodies I could recognize, but had never sung in my life. Thereafter, people started to tell funny stories about the yellow school busEs of their childhood. 
I felt somewhat alienated and puzzled in the bus. Listening to their stories was like watching scenes from American movies, like Forrest Gump-this experience could be due to the fact that I do not share the lived experiences of riding on North America's (or Canada's) yellow school bus. Instead of joining others in sharing stories and songs, I found myself looking out the window.

I used to live in Ottawa. Instead of finding common shared experiences with other people on the bus, I started to look for my "own memory" outside the windows, outside the bus, trying to look for what was familiar to me: the Rideau Canal, grocery stores, the pizzeria I used to go, and so on. When the bus passed my old apartment building (on MacArther Ave), I was very eager to show the people on the bus where I used to live.

I was exploring and sharing my own lived experience and memory in the bus and also outside the bus. In and out. Korean and Canadian, Korean-Canadian. Another reminder that I am living in a hyphenated third space. The unsettling and chaotic feelings of being in the third space while others seem to be in one place, "in order," left me in "disorder." However, as Doll (2012) eloquently explained, such imbalance and "orderly disorder" is a source of creativity (p. 17). Being on the bus may have led me to feel "alienated" and "chaotic" but such chaos led me to become creative through my poems.

\title{
Footprints
}

Karen Meyer, University of British Columbia

Build a school and children will come--somehow. I saw a video taken in rural Iran of parents connecting their children to a zip line that ran over a roiling river to the other side and the school. Many children and their parents walk long distances to a village school. Consider the journey to "school," perhaps under a shady tree, for communities that have fled their homelands due to war and have become refugees.

As acknowledgement of the many unsaid challenges of journeying to school, I offer Abdi's story to the School Bus Symposium, already a contested academic space. His mother's ongoing perseverance led Abdi on a life journey from primary school in Dadaab Refugee Camp (Northeast Kenya), with one teacher for 100 children, to studying on scholarship at a Canadian university.

\section{Hoos (shade)}

\author{
Maxaa geed ugu abuuri \\ saxarahaan?
}

Why plant a tree

in this desert? 
whispers Fatima

her brown hands

dusty with red sand

the cloth, secure

the cloth stretches tight

across tall sticks

planted in sand

Who will carry

my tree its water?

when we leave

go back home

when it is safe

Abdi hears his mother

leaps out the opening

alight to daybreak

his shadow rouses

the faded cloth

like a spirited sapling

Hooyo, Mamma, Hooyo

geed, geed, tree tree

Fatima joins, sings

his English sounds

reaches for a tiny hand

sand, still cool

to bare feet

sends off their footprints

to school

\section{Postscript}

there

it is not safe

going back home

there is no leaving 
the red sand

belonging as if

belonging to refuge

boy child memories

Abdi remembers still

of asking Fatima,

Shall we plant a tree today?

it will give us shade,

hoos

Maxaa geed ugu abuuri

saxarahaan?

\section{Web of Associations}

Veena Balsawer, University of Ottawa

\section{Journey-ing on a Bus}

Bumping over speed-bumps

Ducking under backpacks

Eavesdropping on conversations

Smartphones

Talking

Texting

$$
\text { Blogging }
$$

Tweeting

People

Watching

Reading

Knitting

$$
\text { Eating }
$$

Sleeping (Dreaming)

Capturing

E-scaping land-scapes

So-journing in liminal wor(I)ds

\section{School bus memories}

I used to stand beside the school bus every day

Waving goodbye

As my friends embarked on their homeward journeys 
As I walked home

I envied them all my imagined school bus adventures

And failed to comprehend when they said / was the lucky one!

\section{Winter Palimpsest}

\section{Robert Nellis, Red Deer College}

At the School Bus Symposium, we pile on, find places to sit (Someone sits beside me - yes!), and then take off - wildish wind blowing through the open windows, gears grinding as we turn the corner and head out.

Such a fascinating event and invitation to reflect upon one's experiences on the school bus, this space of interstitiality, taking children and adolescents from home to the public space of school.

My sense has always been to think of the bus as somewhat unregulated, unstructured, and, in this sense, possibly more dangerous (at least to the ego) than school itself. Some may imagine the bus as more open and free than the structures of school. My impression finds it somewhat differently than that. I find it a place of riskbut, today at this symposium, possibly also of an opening.

As folks share their school bus stories, for a few moments, I feel lingeringly as a pretender. I think of myself as actually not having taken the school bus as a kid. While this was true for most of my school career, it is not the whole story (if such a story is possible)...

It may be hard to believe for some who know me, but in grade 8 , I was kicked out of school! As a result, I needed to take a school bus to another part of town for the rest of junior high. The bus was for a high school, across the field from where I was now attending. Curiously, I found the high school kids to be way more accepting and kind than the kids my own age.

One winter morning, the yellow bus coming around the corner, an older girl in a red and white jacket, faded ski tags on the zipper, squeezes the lit ember off her cigarette and drops the butt into her pocket. 


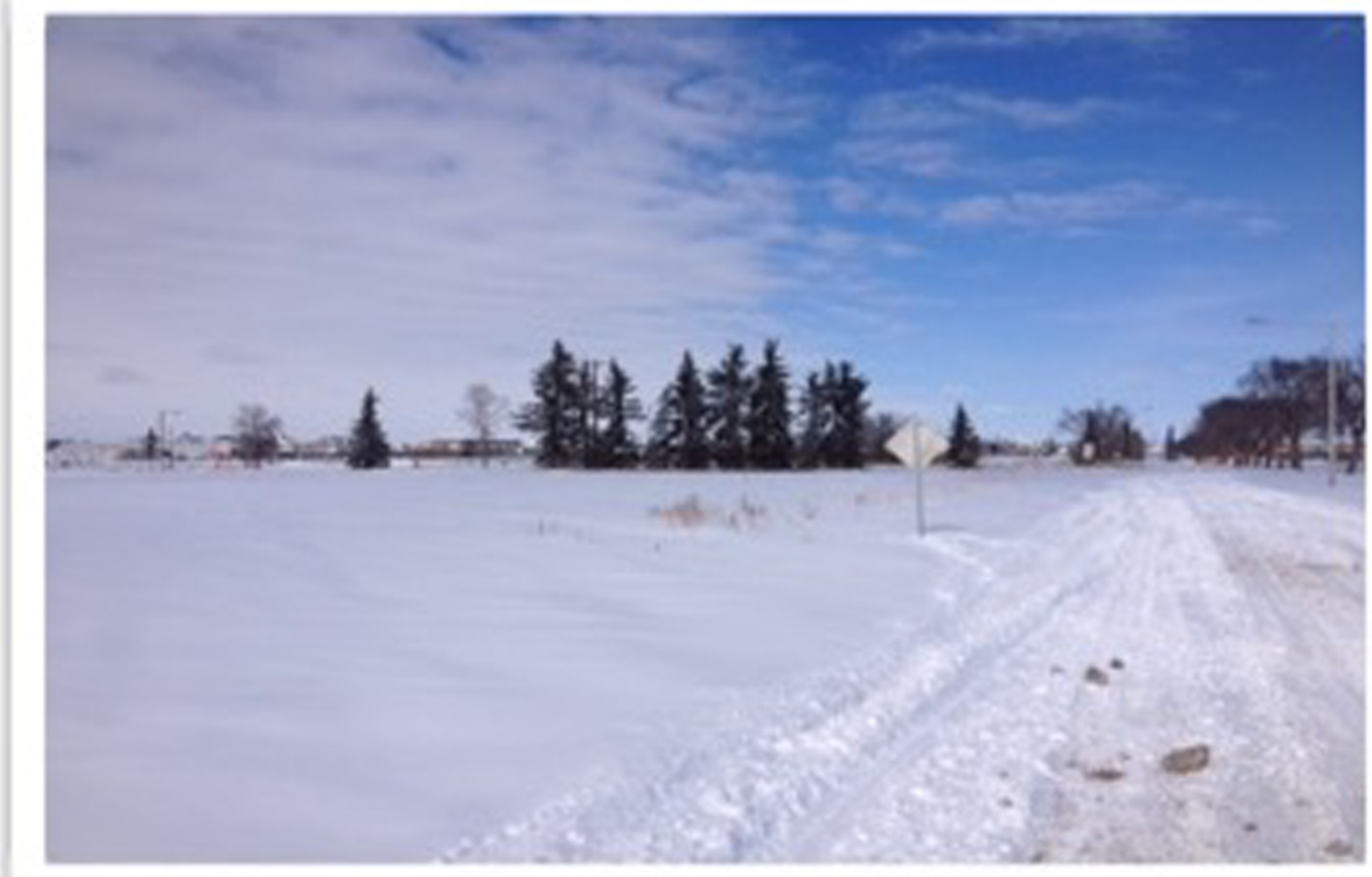

Figure 7: Winter palimpsest, road to school. Photograph by Robert Nellis

Riding on the school bus for the Symposium, outside the conference's rooms, halls, and building, I feel myself also outside the stories I usually tell myself (or not) about school days and school bus riding. After Denzin (2014), I tentatively perform an arrival, if not to some recovered truth, then possibly to a permission to consider a different story...

\section{Buses \& Bees}

\section{Pamela Richardson, Royal Roads University}

1.

Stand on a corner with frozen cheeks, snot mittens, feet in plastic milk bags to waterproof your boots.

Dwarfed by the snow bank. Look back, and wonder: Was I once 
smaller than a Scarborough

snow bank? Or is it

poetry talking?

2.

Snow banks were mountainous

and dirty that winter.

Popsicled children

waited an eternity.:

That rumbling bus

collected us in its own time.

On the dreaming side of the year, bumblebees were everywhere.

This was before the words

colony and collapse

coupled in an unholy union.

And now: how is a cucumber?

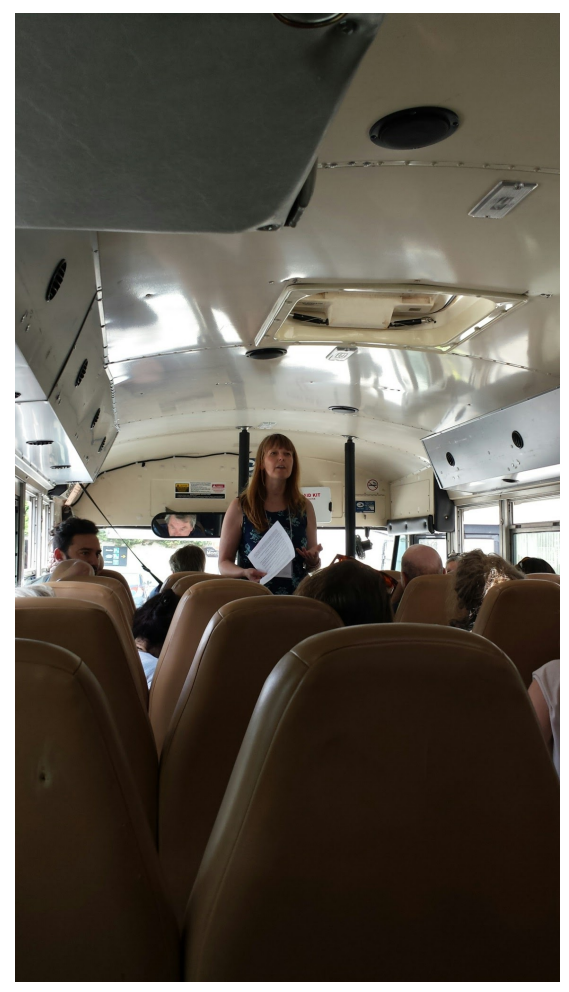

Figure 8: Pamela Richardson, the master of ceremonies. Photograph by Veena Balsawer 
Bused by a mechanical eventuality

did we believe

bees to be a right, and not

a fragile contract?

We did not walk to school

on our own plastic feet

but rolled in a

yellow and black striped

bumble bus.

3.

One morning, overheat in your

pouffy snowsuit

and puke all over

the forest green

Naugahyde.

Be bullied by a girl

whose mother ignored her, whose father lived overseas, and whose younger sister was said to be brilliant.

Never learn what happened to her.

Never forget her.

4.

On schedule at 8:07, the bus opens its maw to receive you.

Feel the blast of its sweaty

breath on your innocence.

Ascend into its gullet.

You are a treat:

Soft and delicate.

Unhardened by life.

Fresh as a bun and

and chubby as a pumpkin.

5.

Digression!

Here is a drinking game for

when you are older and in need: 

Every time an academic uses the
word "complex,"
tilt back your head,
swallow the elixir.
Do not expect to arrive
as planned or on time
ever again.

6.

The first time you have to take a school bus, hide behind the lamppost out of sight.

Become a kindergarten drop out.

Live your life over again.

Go to Leo Tolstoy's Hedge School.

Learn from the story of grass how

paths are created by many

feet finding their way.

Only read books with

sky on the cover like

Dostoevsky.

Think wild thoughts

inseminated by the power of

of souls born out of time.

Walk on fresh soil daily.

Let your feet on the ground

be your text.

Be smaller than a snow bank.

Hide behind lampposts.

Seek bees.

\section{School Bus}

Kathy Browning, Laurentian University

Get on the Bus. Get on the Bus. Get on the bus.

The School Bus.

This School Bus Symposium was a trip packed with fun activities and creative friends. We sang school bus songs, listened to poetry, wrote poems, read poems and generally had a great time. It was a time away from the regular academic stream where we were encapsulated in a bus. This spurred poetry about the bus where many could share their poetry and stories about bus experiences. What did it mean to take a school bus to school? 
Sean Wiebe, Diane Conrad, Lynn Fels, Pamela Richardson, Karen Meyers, and Mitchell McLarnon came prepared with poetry that was shared and well received. It was a new context upon which to focus on poetry as we rode along streets with scenery swirling by. Some of the poetry read inspired us to write our own poems on coloured sticky tabs.

When asked to write down words that were inspired by text in the poems and as a Visual Artist I naturally drew pictures instead as I think visually and not primarily in text. I did this so naturally that I didn't realize that I wasn't writing words! Odd, I must have been tired. These are my rough notes:
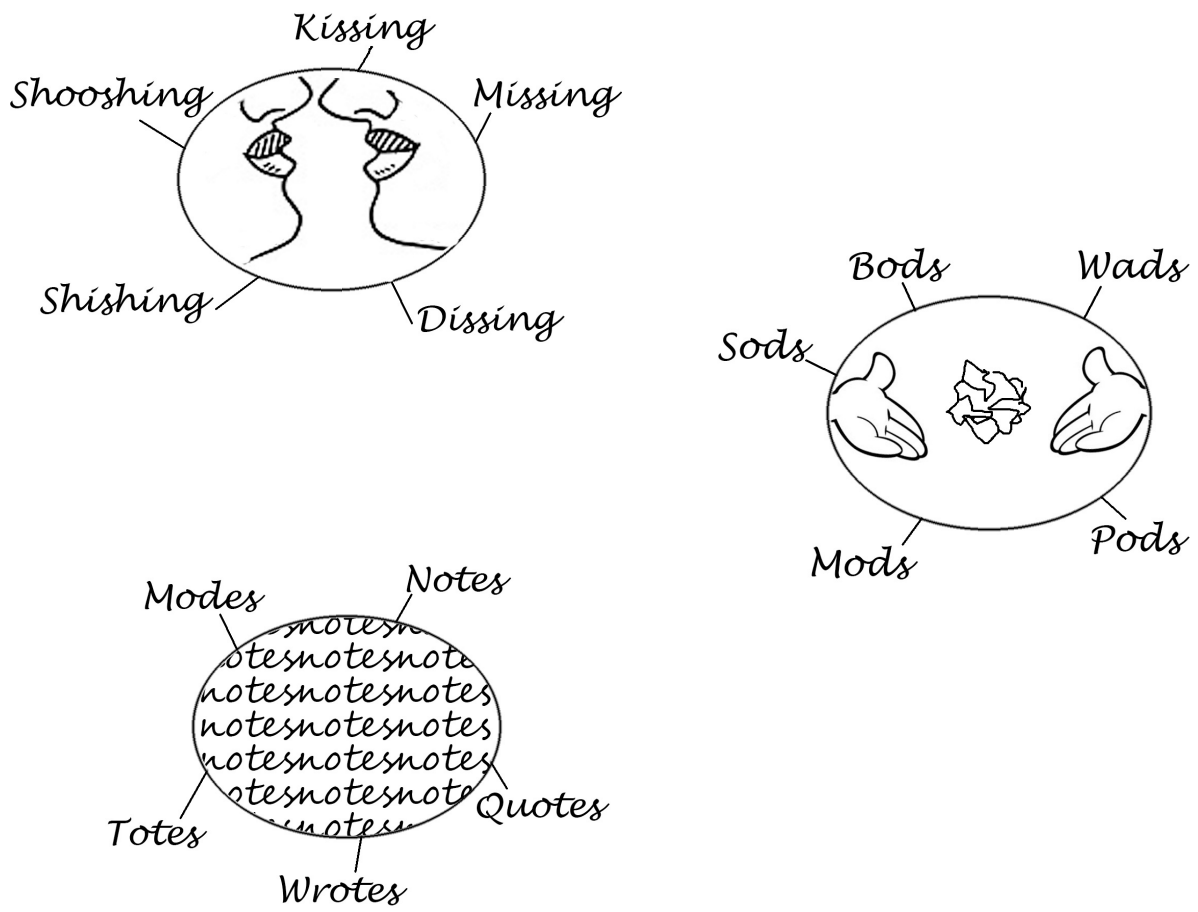

These notes led to the following poems:

\title{
Bus Inspired Poem
}

\author{
No Kissing \\ No Pissing \\ No Shishing
}




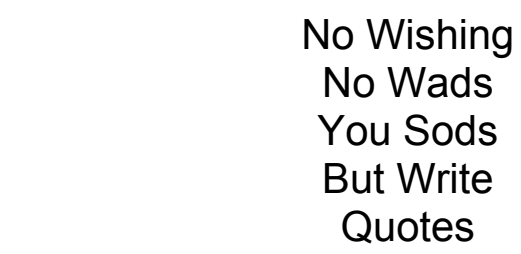

Make Notes of What you Wrote Mod Tods

$\&$ Put them in your Totes.

We looked inside and outside the bus, out the window and wrote poems from text that we saw.

\title{
Bus Environment Poem
}

\author{
NCO You \& Me \\ Emergency! \\ Air Plane \\ Wrong Again?! \\ Hillsdale \\ All's Well \\ 1st Aid Kit \\ What a Hit!! \\ Blue Bird Home \\ Want to Rome \\ This is Not a Poem \\ Although, It is My Poem!
}

I took some photographs of creative friends on the bus and then suggested the group photograph below outside of the bus.

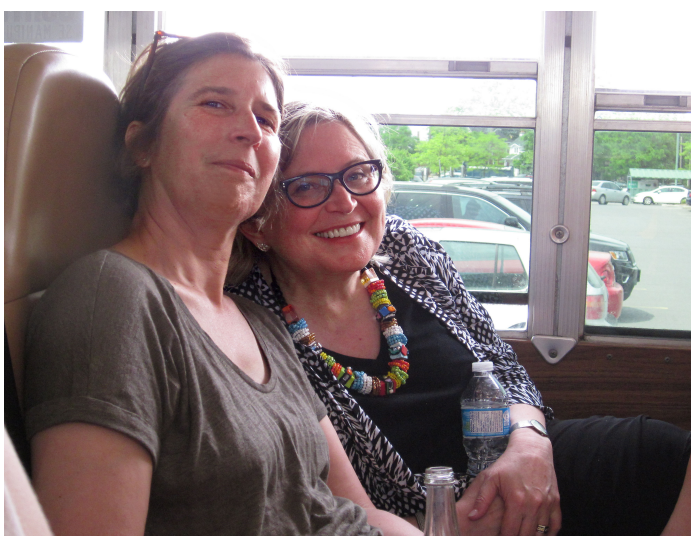

Figure 12: Kathryn Rickets (left) \& Rita Irwin (right)

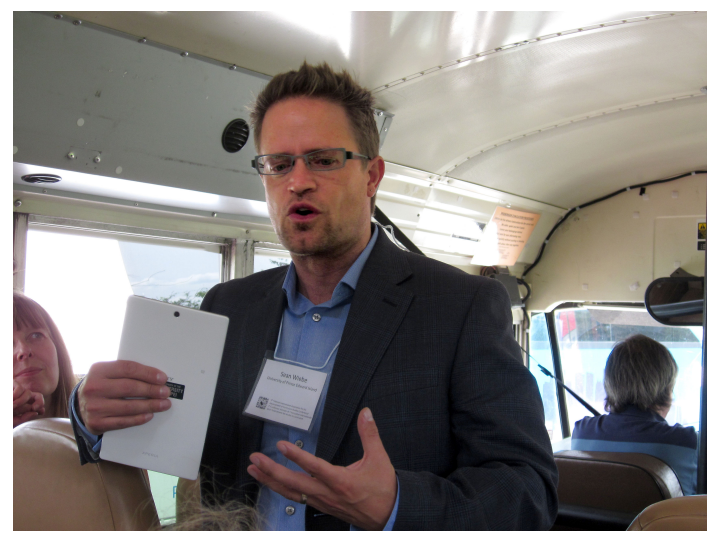

Figure 13: Sean Wiebe presenting his poems 


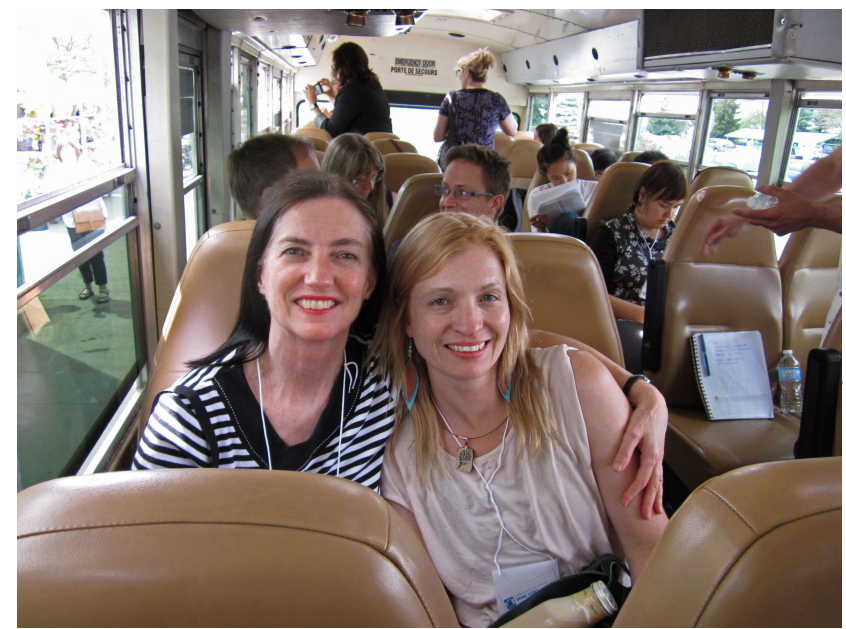

Figure 14: Kathy Browning (left) and Julie Vaudrin-Charette (right)

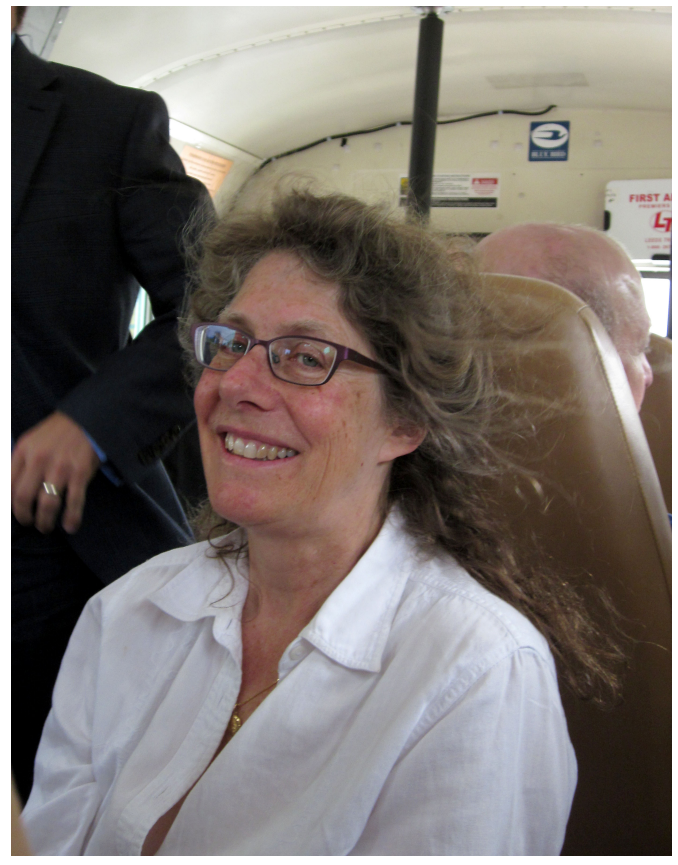

Figure 15: Lynn Fels

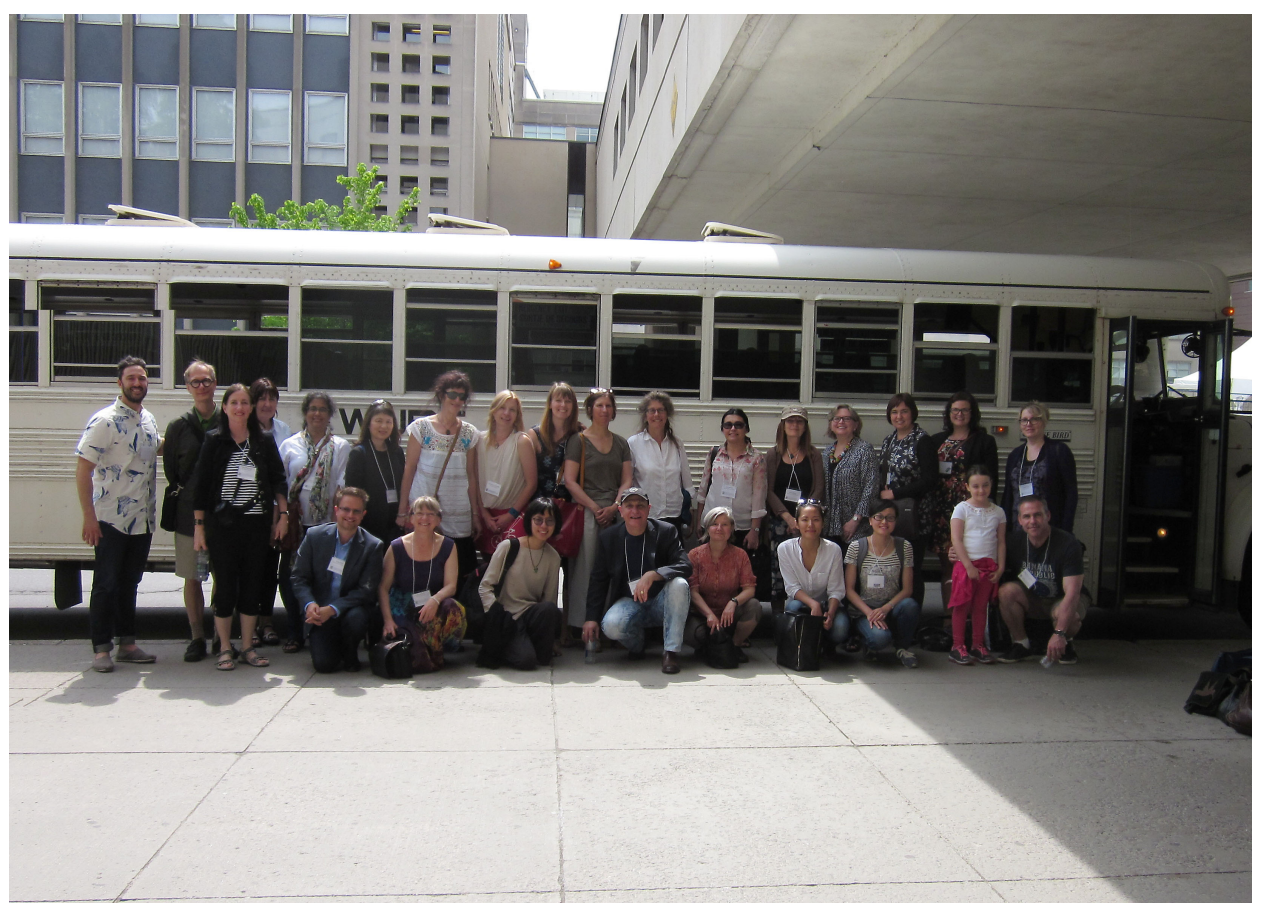

Figure 16: The aftershot of the School Bus Symposium 


\section{References}

Aoki, T. T. (1993). Legitimating lived curriculum: Towards a curricular landscape of multiplicity. Journal of Curriculum and Supervision, 8(3), 255-268.

Aoki, T. T. (1991/2005). Teaching as indwelling between two curriculum worlds. In W. F. Pinar \& R. Irwin (Eds.), Curriculum in a new key: The collected works of Ted. T. Aoki (pp. 159-165). Mahwah, NJ: Lawrence Erlbaum..

Battiste, M., Kovach, M., \& Balzer, G. (2010). Celebrating the local, negotiating the school: Language and literacy in Aboriginal communities. Canadian Journal of Native Education, [Aboriginal Englishes and Education Supplement](32), 4-12.

Bourdieu, P., \& Thompson, J. B. (1991). Language and symbolic power. Boston: Harvard University Press.

Blood, N., Chambers, C., Donald, D., Hasebe-Ludt, \& Big Head, R. (2012). Aoksisowaato'op: Place and story as organic. In N. Ng-A-Fook \& J. Rottmann (Eds.), Reconsidering Canadian curriculum studies: Provoking historical, present, and future (pp. 47-82). New York: Palgrave Macmillan.

Byram, M. (2010). Linguistic and cultural education for building and citizenship. Modern Language Journal, 94(2), 317-321.

Campano, G. (2007). Immigrant students and literacy: Reading, writing, and remembering. New York, NY: Teachers College Press.

Chambers, C. (1999). A topography for Canadian curriculum theory. Canadian Journal of Education, 24(2), 137-150.

Corntassel, J. (2009). Indigenous storytelling, truth-telling, and community approaches to reconciliation. English Studies in Canada, 35(1), 137-159.

David, T., Goouch, K., \& Powell, S. (2015). The Routledge international handbook of philosophies and theories of early childhood education and care (pp. 495-497). London: Routledge.

Denzin, N. K. (2014). Interpretive autoethnography (2nd ed.). Thousand Oaks, CA: Sage.

Doll, W. E. (2012). Complexity and the culture of curriculum. Complicity: An International Journal of Complexity and Education, 9(1), 733-768.

Dubose Brunner, D. (1994). Inquiry and reflection: Framing narrative practice in education. Albany, NY: State University of New York Press. 
Egéa-Kuehne, D. (2012). Provoking curriculum studies in multicultural societies. In N. Ng-A-Fook \& J. Rottmann (Eds.), Reconsidering Canadian curriculum studies: Provoking historical, present, and future perspectives (pp. 137-146). London: Palgrave Macmillan

Eisner, E. W. (1985). The educational imagination. New York: Macmillan.

Eisner, E. W. (2002). What can education learn from the arts about the practice of education? The encyclopedia of informal education [Online]. Retrieved from: http://www.infed.org/biblio/eisner_arts_and_the_practice_of_education.html

Falconi, E. (2013), Storytelling, language shift, and revitalization in a transborder community: "Tell it in Zapotec!" American Anthropologist, 1(15), 622-636. doi: 10.1111/aman.12049

Farley, L. (2009). Radical hope: On the problem of uncertainty in history education. Curriculum Inquiry, 39(4), 537-554.

Fels, L. (2010). Coming into presence: The unfolding of a moment. Journal of Educational Controversy, 5(1) [Online]. Retrieved from: http://cedar.wwu.edu/jec/vol5/iss $1 / 8$

Greene, M. (1988). The dialectic of freedom. New York: Teachers College Press.

Greene, M. (1995). Releasing the imagination: Essays on education, the arts, and social change. San Franscisco, CA: Jossey-Bass Publishers.

Holzman, L. (2008). Vygotsky at work and play. New York: Routledge.

Leggo, C. (2007). Writing truth in classrooms: Personal revelation and pedagogy. International Journal of Whole Schooling, 3(1), 27-37.

Moore, T. (1996). The re-enchantment of everyday life. New York, NY: Harper Perennial.

Pinar, W. F. (2010). Notes on a blue guitar. Journal of Educational Controversy, 5(1) [Online]. Retrieved from: http://cedar.wwu.edu/jec/vol5/iss1/18h

Predergast, M. (2009) Introduction: The phenomena of poetry in research: "Poem is what?" Poetic inquiry in qualitative social science research. In M. Prendergast, C. Leggo, \& P. Sameshima, Poetic inquiry: Vibrant voices in the social sciences (pp. xix-xlii). Rotterdam, NL: Sense Publishers.

Robinson, D. V. \& Sharma, R. (2015). Marginalization. In S. Thompson (Ed.), Encyclopedia of diversity and social justice, vol. 1 (pp. 495-497). London: Rowman \& Littlefield. 
Simon, R. (2013) Towards a hopeful practice of worrying: The educative responsibilities of Canada's truth and reconciliation commission In J. Henderson, \& P. Wakeham (Eds.), Reconciling Canada: Critical perspectives on the culture of redness, (pp. 156-183). Toronto, ON: University of Toronto Press.

Simpson, L. B. (2014). Land as pedagogy: Nishnaabeg intelligence and rebellious transformation. Decolonization: Indigeneity, Education \& Society, 3(3), 1-25.

Stanley, T. (1999). A letter to my children: Historical memory and the silences of childhood. In J. P. Robertson (Ed.), Teaching for a tolerant world, Grades K-6: Essays and resources, (pp. 34-33). Urbana, IL: National Council of Teachers of English.

Tuck, E. \& Gaztambide-Fernández, R. (2013). Curriculum, replacement, and settler futurity. Journal of Curriculum Theorizing, 29(1), 72-89.

Vygotsky, L. S. (1967). Play and its role in the mental development of the child. Journal of Russian and East European Psychology, 5(3), 6-18. 